\title{
Negar Habibi. « 'Ali Qoli Jebadar et l'enregisrement du réel dans les peintures dites farangi sazi »
}

\section{Alexandra Van Puyvelde}

\section{Q OpenEdition \\ 1 Journals}

\section{Electronic version}

URL: http://journals.openedition.org/abstractairanica/47942

DOI: 10.4000/abstractairanica.47942

ISBN: 1961-960X

ISSN: 1961-960X

Publisher:

CNRS (UMR 7528 Mondes iraniens et indiens), Éditions de l'IFRI

Electronic reference

Alexandra Van Puyvelde, "Negar Habibi. « 'Ali Qoli Jebadar et l'enregisrement du réel dans les peintures dites farangi sazi »", Abstracta Iranica [Online], Volume 40-41 | 2019, document 7, Online since 15 July 2019, connection on 26 April 2021. URL: http://journals.openedition.org/abstractairanica/47942 ; DOI: https://doi.org/10.4000/abstractairanica.47942

This text was automatically generated on 26 April 2021.

Tous droits réservés 


\title{
Negar Habibi. « 'Ali Qoli Jebadar et l'enregisrement du réel dans les peintures dites farangi sazi »
}

\author{
Alexandra Van Puyvelde
}

\section{REFERENCES}

Negar Habibi. « 'Ali Qoli Jebadar et l'enregisrement du réel dans les peintures dites farangi sazi », Der Islam, vol. 94 (2017), p. 192-219

1 This article is a mainly iconographic study of five paintings that were signed by or attributed to 'Ali Qoli Jebadar. This so-called farangi sazi- artist was active at the Safavid court of Shah 'Abbas II (r. 1642-1666) and Shah Soleyman (r. 1666-1694). With this study the author wants to demonstrate that "Ali Qoli Jebadar observed and "registered" the reality of daily life at the Safavid court, rather than depicting an ideal, timeless world. She does this by confronting certain subjects, objects or persons in the paintings with written sources, in particular with the travel accounts of Jean Chardin and with two Safavid administrative chronicles, the Dastur al-moluk and the Alqab va mavajeb doreh-ye safavieh.

2 The five paintings by 'Ali Qoli Jebadar, which the author analyses, are from two albums, kept in The Institute of Oriental Manuscripts of the Russian Academy of Sciences in St Petersburg:

3 - "Shah Soleyman and his courtiers," signed, album E-14, f. 98r.

4 - "The royal hunt," not signed, St Petersburg, album E-14, f. 100r.

5 - "The presentation of the horses to the king in the presence of the amir-e akhor bashi," not signed, St Petersburg, album E-14, f. 96r.

6 - "Shah Soleyman with a nobleman and a young man," signed, album E-14, f. 96r.

7 - "Mirza Jalal with a falcon in hand," not signed, album D-181, f. 1 a. 
Only "Shah Soleyman and his courtiers" and "The presentation of the horses to the king in the presence of the amir-e akhor bashi" are illustrated in the article.

9 The author sees in certain represented subjects (e.g. the royal hunt and the royal assembly), objects (e.g. the crown and seat of Shah Soleyman in "Shah Soleyman and his courtiers") and individuals (e.g. the mehtar-e rekab khaneh, i.e. the master of the royal wardrobe, in "Shah Soleyman with a nobleman and a young man") a visual representation of descriptions in JeanChardin's travelogue and in the Iranian chronicles. She thus considers the paintings as a representation of real life at court.

10 The author also notes that some of the individuals in the paintings show more "personalized" facial features than others, who show more stereotypical or repetitive features. These personalized representations are examples of portrait art (or at least of attempts to), a new genre that was apparently well received by the nobles at the Safavid court.

11 To the author, it seems likely that the paintings discussed respond to an explicit demand and to the evolving tastes of 'Ali Qoli Jebadars clients, who belonged to the important personalities at the Safavid court.

\section{AUTHORS}

\section{ALEXANDRA VAN PUYVELDE}

Royal Museums of Art \& History, Bruxelles 